\title{
CKD-EPI Cystatin C Formula
}

National Cancer Institute

\section{Source}

National Cancer Institute. CKD-EPI Cystatin C Formula. NCI Thesaurus. Code C161339.

A formula to estimate glomerular filtration rate that takes into account sex, age, race, and serum cystatin C (Scys). eGFR(mL/min/1.73 m2)=133 x min(Scys/0.8, 1)^-0.499 $\times$ max (Scys/0.8, 1)^-1.328 $0.996^{\wedge}$ Age $\times 0.932$ [if female]. (Inker LA, Schmid CH, Tighiouart $H$, et al. Estimating glomerular filtration rate from serum creatinine and cystatin $\mathrm{C}$. $\mathrm{N}$ Eng IJ Med. 2012;367(1):20-29.) 